\title{
ASSESSMENT AND EVALUATION OF PRODUCTION EFFICIENCIES IN TEXTILE INDUSTRY THROUGH QUALITY OF WORK LIFE
}

\author{
Venkatesh J, Aarthy C* \\ Department of Management Studies, Anna University, Regional Centre Coimbatore,Coimbatore - 641 047, Tamil Nadu, India \\ e-mail: mailtoaarthy@gmail.com
}

\begin{abstract}
:
The success of any organisation is dependent on how effectively it attracts recruits, and the manner in which it motivates and retains its workforce. To cope up with the current situations, managements must be flexible enough in dealing with their workforce and ensure loyalty in their employees. In order to satisfy the employees and achieve organisational goals, the management must adopt new approaches to improve the quality of work life of employees. This paper aims to measure the factors influencing the quality of work life and the impact of quality of work life on employees' performance. A sample of 150 employees from a textile industry was selected and the study reveals that organisational culture, training and development, compensation and rewards, and job satisfaction differ from department to department, which have great impact on the quality of work life of employees. The positive finding in this study is that there is a healthy relationship among the subordinates and superiors which leads to effective communication and cooperation. Thus, quality of work life of employees has a positive impact on productivity of the employees.
\end{abstract}

\section{Keywords:}

Quality of work life, job satisfaction, textile industry, motivation

\section{INTRODUCTION}

The textile industry in India is an integrated multinational setup that involves various activities like spinning, weaving, dying and ready-made garments. The manufactures maintain a high standard of quality of the products being produced but do not focus on the human efficiency behind this productivity. Even large scale sectors fail to develop a quality working environment for their employees, which will have an adverse effect on employees' health and safety. It is the primary duty of the management to provide a sense of belonging to the workgroup as well as a sense of worth and respectability. The contribution of garment industry towards foreign exchange earnings accounts for $16 \%$ and comprises a workforce of 3.8 million. After the implementation of Multi Fibre Agreement Act, nations of the world faced a heavy competition to grab business opportunities. Besides this competition, the work pressure has been constantly increasing and the conditions are going bad from worse. While the garment industry is one of the biggest sources of export, with significant and rapid increase in growth, there has been a corresponding race to the bottom insofar as labour standards and wages are concerned [9]. Quality of work life ( $Q W L)$ is viewed as an alternative to the control approach of managing people. The QWL approach considers people as an asset to the organisation rather than as cost. It believes that people perform better when they are allowed to participate in managing their work and in decision making. This approach motivates people by satisfying not only their economic needs but also their social and psychological ones [6]. To satisfy the new generation workforce, managements need to concentrate on job designs and organisation of work. Further, the workforce today is realising the importance of relationships and is trying to strike a balance between career and personal lives. It is very important for employees to have a sound mindset in their work field in order to utilise their full potential and add value to the organisation. A satisfied employee is an asset for a company as he or she will ensure full productivity.

There is much concern today about decent wages, convenient working hours, conducive working conditions, etc. There is no generally acceptable definition about this term "QWL". However, some attempts were made to describe this term. For some it refers to the favourableness or unfavourableness of a job environment for employees. J. Richard and J. Lay define QWL as 'the degree to which members of a work organization are able to satisfy important personnel needs through their experience in the organization." In recent years, employers and employees have started realising the importance of overall development of human resources. In spite of the tremendous development in the areas of technology, marketing and finance, overall organisational situation cannot be improved unless good human resource development practices are introduced. Maintaining a traditional personnel department and providing minimum on-the-job training to the employees is hardly sufficient. An overall development of employees as human resources is to be stressed upon. Though monetary benefits still occupy the first place in the list of elements of QWL, other elements like physical working conditions, job restructuring and job redesign, career development, and promotional opportunities are gaining importance rapidly. As such, the workers expect the management to improve all these facilities thereby improving the QWL. 


\section{BACKGROUND}

Buchanan and Boddy consider QWL as a factor in reducing grievances and absenteeism [1]. Thompson states that QWLrelated programmes emphasise teamwork, awareness and workforce skills. Quality of life has been recognised as an important construct in a number of social and medical sciences such as sociology, political science, economics, psychology, philosophy, marketing, environmental sciences and medicine [7]. Gehring et al (2002) [9] state that consensus exists among professionals from various fields that stress-related psychological or health problems constitute important issues in contemporary work environment. QWL is defined as "employee satisfaction with a variety of needs through resources, activities, and outcomes stemming from participation in the workplace" [8]. According to Grayson, QWL is important to organisational performance [4]. Gosh stated that QWL is an important factor that affects motivation at work [3]. QWL programmes have two aims: to improve the productivity and the satisfaction of employees [2]. Oshagbemi conceptualises job satisfaction as a general attitude [10] and, therefore, QWL can be described as work environment that is conducive to the forming of a positive attitude or emotional reaction towards the work environment. QWL is a philosophy of management that believes in a cooperative relationship between employees and managers and also that every employee has the ability and right to offer his or her intelligence and useful inputs into decisions at various levels in the organisations [5].

\section{METHODOLOGY}

The main research problem is to analyse the QWL of employees in textile manufacturing firms. Descriptive research design is used to ascertain and describe the characteristics of the variables of interest. A questionnaire was developed and distributed to employees on a simple random sampling basis. In all, there were 150 respondents from the total universe of 264 . The analysis is carried over with simple percentage, Chi-Square, ANOVA and correlation technique using SPSS software.

\section{RESULTS}

The study reveals that the majority (31.3\%) of the respondents in textile industry are in the age group of 20-25 and among them $51.3 \%$ are male and $48.7 \%$ female. The qualification of the respondents is shown in Figure 1.

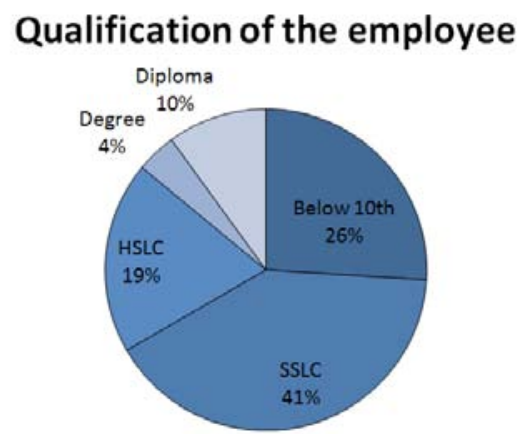

Figure 1. Qualification of Respondents.
When we analyse the income of the employees, the majority $(48 \%)$ of the respondents are in the band width of Rs. 50018000 income level which depicts that respondents belong to a relatively high income group. The Chi-Square test between designations of respondents and their work environment clearly states that there exists a significant relationship between designation and satisfaction about work environment. For this purpose, hypotheses are framed (NULL HYPOTHESIS $(\mathrm{Ho})$ : There is no significant relationship between Designation and Satisfaction about Work Environment. ALTERNATE HYPOTHESIS (H1): There is significant relationship between Designation and Satisfaction about Work Environment). When calculated, the table value is lesser than the computed value and so null hypothesis is rejected and the alternate hypothesis is accepted as shown in Table 1.

Table 1. Designation vs. Satisfaction about Work Environment.

\begin{tabular}{|c|c|c|c|}
\hline & Value & DF & $\begin{array}{c}\text { Asymp. Sig } \\
\text { (2-sided) }\end{array}$ \\
\hline Pearson Chi-Square & 36.192 & 18 & 0.007 \\
N of valid cases & 150 & & \\
\hline
\end{tabular}

Degree of freedom $=18$; Level of significance $=0.02$;

Calculated value $=36.192 ;$ Tabulated value $=32.346$

The one-way ANOVA technique when tested against designation with overall working environment verified whether the demographic profile has an impact over the overall QWL. The obtained significant value $(0.236)$ in Table 2 is greater than the 0.05 level of significance. Hence null hypothesis is accepted (Null hypothesis: There is no significant difference between designation across overall working environment). It indicates that the overall working environment does not differ significantly on the basis of designation.

Table 2. ANOVA - Designation with Overall Working Environment.

\begin{tabular}{|c|c|c|c|c|c|}
\hline Source & $\begin{array}{c}\text { Sum of } \\
\text { Squares }\end{array}$ & Df & $\begin{array}{c}\text { Mean } \\
\text { Square }\end{array}$ & F & Sig. \\
\hline Between Groups & 26.416 & 6 & 3.569 & 1.357 & 0.236 \\
\hline Within Groups & 376.157 & 143 & 2.630 & & \\
\hline Total & 397.573 & 149 & & & \\
\hline
\end{tabular}

The ANOVA test also reveals that overall QWL differs among employees of different departments. So the department heads should take the necessary measures to eliminate these discriminations for bias among employees of the same organisation or it may create dissatisfaction that will eventually affect the cooperation and communication among them. Table 3 depicts the correlation among various dimensions of QWL.

It is inferred from the above table that all the dimensions are positively and significantly correlated with the QWL at $1 \%$ level of significance. It is also found that all these dimensions are highly correlated with each other. 
Table 3. Correlation of Various Dimensions of QWL

\begin{tabular}{|c|c|c|c|c|c|c|c|c|}
\hline & & OWE & OOCC & ORC & OTD & OCR & OJS & OQWL \\
\hline \multirow{3}{*}{$\begin{array}{l}\text { Overall Working } \\
\text { Environment }\end{array}$} & Pearson Correlation & 1 & $0.485^{\star *}$ & $0.527^{* *}$ & $0.548^{* *}$ & $0.217^{\star *}$ & $0.421^{* *}$ & $0.752^{* *}$ \\
\hline & Sig. (2-tailed) & & 0.000 & 0.000 & 0.000 & 0.008 & 0.000 & 0.000 \\
\hline & $\mathrm{N}$ & 150 & 150 & 150 & 150 & 150 & 150 & 150 \\
\hline \multirow{3}{*}{$\begin{array}{l}\text { Overall Organisation } \\
\text { Culture and Climate }\end{array}$} & Pearson Correlation & $0.485^{\star \star}$ & 1 & $0.316^{* *}$ & $0.562^{\star \star}$ & $0.316^{\star *}$ & $0.324^{* *}$ & $0.719^{* *}$ \\
\hline & Sig. (2-tailed) & 0.000 & & 0.000 & 0.000 & 0.000 & 0.000 & 0.000 \\
\hline & $\mathrm{N}$ & 150 & 150 & 150 & 150 & 150 & 150 & 150 \\
\hline \multirow{3}{*}{$\begin{array}{l}\text { Overall Relation and } \\
\text { Cooperation }\end{array}$} & Pearson Correlation & $0.527^{\star \star}$ & $0.316^{\star \star}$ & 1 & $0.424^{\star *}$ & $0.231^{\star *}$ & $0.468^{* *}$ & $0.698^{* *}$ \\
\hline & Sig. (2-tailed) & 0.000 & 0.000 & & 0.000 & 0.004 & 0.000 & 0.000 \\
\hline & $\mathrm{N}$ & 150 & 150 & 150 & 150 & 150 & 150 & 150 \\
\hline \multirow{3}{*}{$\begin{array}{l}\text { Overall Training and } \\
\text { Development }\end{array}$} & Pearson Correlation & $0.548^{\star \star}$ & $0.562^{\star *}$ & $0.424^{\star *}$ & 1 & $0.302^{* *}$ & $0.402^{* *}$ & $0.778^{* *}$ \\
\hline & Sig. (2-tailed) & 0.000 & 0.000 & 0.000 & & 0.000 & 0.000 & 0.000 \\
\hline & $\mathrm{N}$ & 150 & 150 & 150 & 150 & 150 & 150 & 150 \\
\hline \multirow{3}{*}{$\begin{array}{c}\text { Overall } \\
\text { Compensation and } \\
\text { Rewards }\end{array}$} & Pearson Correlation & $0.217^{\star *}$ & $0.316^{* *}$ & $0.231^{* *}$ & $0.302^{* *}$ & 1 & $0.171^{* *}$ & $0.567^{* *}$ \\
\hline & Sig. (2 tailed) & 0.008 & 0.000 & 0.004 & 0.000 & & 0.037 & 0.000 \\
\hline & $\mathrm{N}$ & 150 & 150 & 150 & 150 & 150 & 150 & 150 \\
\hline \multirow{3}{*}{$\begin{array}{l}\text { Overall Job } \\
\text { Satisfaction }\end{array}$} & Pearson Correlation & $0.421^{\star \star}$ & $0.324^{* *}$ & $0.468^{* *}$ & $0.402^{* *}$ & $0.171^{* *}$ & 1 & $0.658^{* *}$ \\
\hline & Sig. (2-tailed) & 0.000 & 0.000 & 0.000 & 0.000 & 0.037 & & 0.000 \\
\hline & $\mathrm{N}$ & 150 & 150 & 150 & 150 & 150 & 150 & 150 \\
\hline \multirow{3}{*}{$\begin{array}{l}\text { Overall Quality Of } \\
\text { Work Life }\end{array}$} & Pearson Correlation & $0.752^{\star *}$ & $0.719^{* *}$ & $0.698^{* *}$ & $0.778^{* *}$ & $0.567^{\star *}$ & $0.658^{* *}$ & 1 \\
\hline & Sig. (2-tailed) & 0.000 & 0.000 & 0.000 & 0.000 & 0.000 & 0.000 & \\
\hline & $\mathrm{N}$ & 150 & 150 & 150 & 150 & 150 & 150 & 150 \\
\hline
\end{tabular}

${ }^{* *}$. Correlation is significant at the 0.01 level (2-tailed).

\section{DISCUSSIONS}

The intent of this research is to emphasis the QWL of employees in the textile industry. QWL is vital for job satisfaction, performance and turnover. The respondents state that they need freedom to use their skills in their job and their ideas and suggestions should be valued by the management. Many employees are not aware of the fringe benefits and other allowances given by the management. This indicates their lack of knowledge of various issues in the organisation and lack of communication between the employees and management. The management can give adequate training to their employees to cope up with the current technology upgradation and to improve their skills. The most important aspect to consider is the need of the employees of regular feedback about their performance which will motivate them to greater levels and also to offer correction as needed. The management must give prominence to social integration among the workforce so that all the employees will be informed of issues involving other departments. Accidents can be minimised by ensuring worker safety and providing sufficient allowances in case of accidents as well as medical reimbursements. Many employees believe that money is the motivational factor which keeps them working and at the same time the pay must be connected to the responsibility of each employee; individual recognition too plays a major role. Therefore, the organisation must follow a fair pay strategy regarding the employees and can encourage performance based increments to improve the performance of workers which should be compatible with the existing economic conditions. QWL not only attracts new employees but also retains experienced and talented workers. The management can arrange for free health check up, counselling and tours for the workers so that the employees have a sense of belongingness. An employee who is both mentally and physically sound will show an outstanding performance in the work and the organisation can contribute equally. Thus, to improve the work life the employees should be taken into account during implementation of changes, and they must be encouraged to participate in various technical and other activities including recreational.

\section{CONCLUSIONS}

A few employees feel that they do not have a say in decision making. Hence participation of the employees in decision making will help the organisation retain its employees. Encouragement of innovation and opportunity for career growth among the employees will improve their performance and benefit the organisation in the long run. A sound incentive and 
performance appraisal system would increase the employee's commitment, morale and loyalty to the organisation thereby reducing the attrition rate. The organisation has managed to convey a fair impression. The management should emphasis on importance of social integration in workforce which will ensure that all the members of the organisation have a sense of belonging to a single community. The management must be transparent in their dealings with the employees and encourage them in all activities and so a trustworthy environment must be created. At the same time, frequent research must be carried over by the management to ensure that there is no hindrance for the employees in their work environment. Thus, the quality in work environment is vital for enhanced performance and productivity in the textile sector.

\section{REFERENCES}

[1] Buchanan, D. A., \& Boddy, D. (1982), "Advanced Technology and the Quality of Work Life", Journal of Occupational Psychology, Vol.55, 1-11.

[2] Gardon, Herman (1984), "Making sense of Quality of Work Life Programmes", Business Horizons

[3] Gosh, Subratesh (1992), "Quality of Work Life in Two Indian Organizations Decisions", Vol.19, No.2, pp - 89102.

[4] Grayson, C.J (1973), "Management Science and Business Practice", Harvard Business Review, Vol.51, No.4A
[5] Kumar and Tripati (1993), "Relationship of Need Satisfaction and Desire to Improve Need satisfaction, Perceptual and Motor Skills", 76(3), Part 2.1070-1092

[6] P. Rathamani and Dr. Rameshwari Ramchandra (2013), "A Study on Quality of Work Life of Employees in Textile Industry- Sipcot, Perundurai", IOSR Journal of Business and Management (IOSR-JBM), e-ISSN: 2278-487X. Volume 8, Issue 3 (Mar. - Apr. 2013), PP 54-59.

[7] Rapley, M. (2003): Quality of Life Research: A Critical Introduction, London: Sage.

[8] Sirgy, M.J., Efraty, D., Siegel, P. and Lee, D.J. (2001), "A New Measure of Quality of Work Life (QWL) Based on Need Satisfaction and Spillover Theories", Social Indicators Research, Vol. 55, No. 3, pp 241-302.

[9] Suhasini Singh (2009), "Richer Bosses, Poorer Workers Bangalore's Garment Industry", CIVIDEP, pp.1-28

[9] Thomas M. Gehring, Jeannette Widmer, Oskar Banziger \& Daniel Marti, (2002), "Cognitive elements of empowerment: An Interpretive model of intrinsic task motivation", Academy of Management Review, 15(4), 666-681.

[10] Oshagbemi, T. (1999), "Overall Job Satisfaction: How Good are Single versus Multiple-item Measures", Journal of Managerial Psychology, 14(5), 388-403.

\section{WEBSITES:}

http://www.scribd.com/doc/37205684/Quality-of-Work-Life http://www.scribd.com/doc/48547296/Review-of-litreture-final 